\title{
The IASB's Management Commentary and Modern Paradigms of Management
}

\author{
Przemyslaw Kabalski \\ Faculty of Management, University of Lodz \\ Matejki Street 22/26, 90-237 Lodz, Poland \\ E-mail:pkabal@interia.pl
}

Received: November 28, 2011

Accepted: December 14, 2011

Published: March 16, 2012

doi:10.5539/ijbm.v7n6p90

URL: http://dx.doi.org/10.5539/ijbm.v7n6p90

\begin{abstract}
The aim of the article is to present a critical analysis of Management Commentary (issued by IASB in 2010) in the light of contemporary paradigms of management science. In the author's opinion, these paradigms reflect the economic reality in and outside of business entity and thus should be taken into account while preparing reports such as Management Commentary. Otherwise users of financial reporting will not be provided with relevant and reliable information.
\end{abstract}

Keywords: Management Commentary, Financial reporting, Relevant information, Management paradigm, International Financial Reporting Standards

\section{Introduction}

In December 2010, the International Accounting Standards Board (IASB) published a document entitled IFRS Practice Statement: Management Commentary - A framework for presentation (IASB, 2010b). This is not International Financial Reporting Standard, but a model of good practice (and thus the entities that prepare financial statements in accordance with the International Financial Reporting Standards do not have use it). According to the IASB, the Management Commentary should contain integrated information forming the context in which the users of financial statements interpret the financial situation and financial performance of the company (Note 1). This information reflects the management's view of the events taking place, their causes and conclusions for the future. The Management Commentary should explain all relevant trends and factors determining future results, position and development of the entity. It reflects the current situation and, at the same time, it is a look back and towards the future. Based on the Management Commentary, the users of financial statements will be able to assess the risks and prospects of the business entity and the effectiveness of its strategy. For this purpose, it should contain information that enables understanding (IASB, 2010b, para. 24):

a) the nature of the business,

b) the objectives set by the management and the strategies for meeting those objectives,

c) the most significant resources, risks and relationships,

d) the achieved and expected results of the operations,

e) key performance measures and indicators used by the management to assess the degree of achievement of the agreed goals.

The purpose of this article is a critical analysis of the IASB's Management Commentary in the light of contemporary paradigms of management. Paradigms, which are essentially assumptions about reality, indicate which ideas are accepted and which rejected (Drucker, 2009, p. 11). They express the rationality applicable in a given moment. Therefore, they have a significant impact on both the science and practice of management. In the paradigmatic dimension, they are the key to analyse and describe companies, and subsequently to solve their problems. If the management paradigms reflect the reality within the enterprise and beyond it, every description of a business entity (e.g. in the Management Commentary) inconsistent with these paradigms (or taking them into account to an insufficient extent) will be more or less diverged from the reality. On the basis of the Conceptual Framework of international financial reporting, such information would be useless for users. Let us see whether modern management paradigms are reflected in the document of the IASB. 


\section{Contemporary management paradigms and the content of the Management Commentary}

\subsection{Holistic paradigm and systemic approach}

According to many representatives of economic sciences, the prerequisite for the development of these sciences and their usefulness for the global society is moving away from reductionism towards a holistic approach. According to the holistic approach, the economy is a system composed of various elements, including people (with their different personalities, views and experiences) and the environment (Note 2). Thus, while studying the mechanisms of functioning of the economy, both at macro and micro level, and developing ways to address their shortcomings, what should be taken into account are social, environmental and ethical considerations. This perspective has a growing number of supporters among representatives of science, which makes it possible to say that we are dealing with the formation of a new holistic and ecological paradigm (Kowalczewski, 2008, p.26). This is particularly evident in management science and practice, where concepts integrating management methods with other areas, such as total comprehensive quality and environment management system, are gaining importance (Kowalczewski, 2008, p.27). This trend is also seen more clearly in the field of accounting concepts and methods (e.g. balanced scorecard, target costing and many others) (Note 3).

Does the Management Commentary contain the elements of such a holistic approach to the description of the activities of a company preparing financial statements for a wide range of users? The answer is not clear, but rather in the affirmative. The IASB recommends that the information forming the context of company's business activity is integrated. Holistic approach is therefore by definition inherent in the nature the Management Commentary. On the other hand, the list of elements that should be presented, as defined in the previously quoted paragraph 24 (and subsequent ones constituting its development), omits several important issues (it will be analysed later in the article). One can of course produce arguments to the contrary, saying that this list is not exhaustive and that the IASB states that the exact choice of information presented by the entity depends on the internal and external conditions of its operations. However, it can be assumed that the right solution, clearly demonstrating IASB's holistic approach to the presentation of information in the Management Commentary, would be supplementing the list of its elements (thematic areas). Believing that companies, following a general recommendation, will present an overall picture of their activity is naïve (Note 4).

The IASB's postulate that the elements of the Management Commentary are presented in a way showing their interrelations (interactions between them) is in accordance with the holistic and systemic approach. However, the statement that the users of the Management Commentary (as well as the entire financial reporting, according to the new Conceptual Framework) are the providers of capital may seem contrary to the holistic approach (Note 5). And what about the other stakeholders? However, the fact that the providers of capital are considered the primary users of financial reporting does not necessarily mean reducing the information needs of the other interest groups (see Kabalski, 2009a, 2009b). Summarising the analysis of the Management Commentary for compliance with the holistic approach, it can be found that this approach is present in the IASB's document, but rather implicitly and very generally, and thus insufficiently (in terms of quality of information that will be presented by companies in their Management Commentaries).

In light of the view of the need for a holistic and ecological perspective at explaining the economy and solving its problems, the lack of articulation of environmental issues in the Management Commentary seems of particular importance. It is impossible to deny today that the state of the environment is the result of individual activities of households, businesses and other organisations. No one, be it a single man or a business entity, cannot deny the fact of having an impact on the environment (Note 6). Business entities should inform stakeholders about their impact on the environment, even if this aspect is ignored in their strategy.

Today, while taking economic decisions, one can no longer ignore ethical issues (as well as environmental problems). Ethics is an important element in the holistic approach (Kowalczewski, 2009, p. 26). Specialists in management believe in turn that the erosion of ethical standards (called the crisis of values) taking place in the operation of businesses is detrimental not only from the moral and social standpoint, but also from the point of view of the efficiency of management (Koźmiński, 2004, p. 55). It is related to the decentralisation forced by the operating conditions of modern enterprises. Transfer of the authority to make many important decisions to lower levels is risky if there is no assurance that employees will act honestly. Moral conduct can neither be the result of centrally imposed, uniform and rigid standards, nor can it be forced by the surveillance system (which is expensive and reduces the efficiency of management). It should be the result of individual moral responsibility (Koźmiński, 2004, p. 56). Shaping the moral consciousness of employees can take place by suitably profiled training and ethical leadership (managers of higher levels as examples of ethical behaviour, which will be discussed later in more detail) (Schermerhorn, 2008, pp. 92-94). Information on respecting and promoting 
ethical standards in business, both in external (the company in relations with others) and internal (ethics in reciprocal relationships of employees) dimensions, is undoubtedly important for stakeholders (Note 7). The postulate of disclosure of such information should be clearly articulated in the recommendations on the content of the Management Commentary. The ethical and ecological aspects are obviously interrelated (and more exactly, respect for the environment is one of ethical axioms).

According to representatives of management sciences, one of the increasingly important features of modern enterprises is their multiculturalism (Note 8). Members of the same organisation come from or belong to different ethnic, religious and professional societies. They also differ in outlook, politic views, interests, etc. This cultural diversity creates problems with communication and cooperation. Therefore, the management of cultural diversity becomes an increasingly important part of corporate strategy. The objective of management is to minimise the risks while maximising the opportunities provided by multiculturalism of employees. Managing cultural diversity is made at the level of organisational culture, and its effectiveness depends on the strength of this culture (Koźmiński, 2004, pp. 179-188). In its recommendations concerning the Management Commentary, the IASB states that the management of an entity should provide a description that allows users of financial statements to understand the company (to know its character). As the elements of such a description, the processes and structure are enumerated. What was skipped was the organisational culture, and the issue of cultural diversity has not been articulated (Note 9). It is an essential omission, because it is impossible to understand the company without information about such an important aspect of its operations. It is believed that the characteristics of the employees that allows sketching, at least in general outline, the map of cultural diversity of the company should be a listed element of the Management Commentary. What is also important is the information on whether and how the management of the entity manages multiculturalism.

\subsection{Process concept of a company and the paradigm of value}

Changes in internal and external conditions of operation of companies that occurred in the post-industrial era changed the concept of the company. Nowadays, a company is seen as a process organisation, i.e. a sequence of processes forming a whole, while each of the processes is focused on creating value for the customer (see Szychta, 2007, pp. 109-110; Suszyński, 2007, p. 79). Processes ,go across traditional functional organisation of the company. Moreover, the value chain extends beyond the boundaries of a given business entity, „touching” its suppliers, subcontractors and customers. The process of value creation can and even should be coordinated in an inter-organisational way. To make such coordination possible, it is necessary to build relationships different from the traditional relationships of an enterprise with its business partners (the issue of such relationships will be discussed later in this article). Let us consider whether the value chain will be reflected in the Management Commentaries of the companies?

The IASB recommends that the information on the nature of the company should include its processes. Slightly further, it postulates that the way the company creates value should be described. It seems that what is meant here is rather the value for shareholders, but it can or even should be understood in a broader sense - the value for customers, value for the owners and the value for other stakeholders. The value for the customer is not identical with the value for the shareholders or the value for other stakeholders, although they are closely linked. Creating value for customers is a prerequisite for the profitability of the company (which in turn, just as the cost of capital, is a determinant of value for shareholders). The studies show that there is no conflict between the operation of a business entity for broader public good and its financial performance. What is more, acting in a socially responsible way often goes hand in hand with above-average financial performance. This in turn enables deeper involvement in activities for the society and natural environment (see Makower, 1994; Waddock, Grave 1997; after: Schermerhorn, 2008, p. 97). Thus, the concept of value can (and should, according to the holistic approach) be understood very broadly. Was this the intention of the IASB and will the management boards of the companies see the issue of value in this way in developing their commentaries? Probably not. There is therefore no certainty that the Management Commentary will reflect the value chain of the company. There would not be these doubts if the question of the value for customers were clearly articulated by the IASB (as well as the value for other stakeholders).

\subsection{The paradigm of relationships}

Another new trend in the functioning of companies resulting in the formation of a new paradigm in management sciences is to change the relationship of the business entity with customers, suppliers and even competitors. Enterprises are strengthening ties with their suppliers and customers. It is not only about the reliability of deliveries. Hammer writes $(2001$, p. 84$)$ that the chances of victory in the fight against competition belong to those companies that can work closely with their partners beyond the traditional boundaries between companies. 
The harmonisation of activities between customers and suppliers allows a jump from effectiveness to super-effectiveness. Streamlining the processes occurring at the interface between companies (e.g. delivery of materials) results in cost savings, acceleration of operations (e.g. by avoiding duplication of efforts) and increased quality. The process of creating the value for customers is coordinated by the cooperating companies (Koźmiński, 2004, p. 121). This applies not only to the supplier-customer relationships (in which two previously separate processes become one integrated value chain), but also to horizontal interactions (e.g. joint advertising campaigns or research, sharing distribution channels). Therefore, what becomes the source of value is the management of relationships between companies (Koźmiński, 2004, p. 122). What is more, in the new model of the economy, competition takes place not between individual companies, but between business collectives (Kowalczewski, 2009, p. 80). The competitive position of a given business entity will depend on what network of relations it forms with customers, suppliers and other business partners (Note 10). With such dependencies, value is created not by individual undertakings, not even by a chain of companies related vertically as suppliers and customers, but by a whole network of actors. Coordination in the process of value creation concerns not only the value for customers, but also the value for other stakeholders. It is enough to cite the fact that it is impossible to solve the problem of ecological harmfulness of a given product if you do not look at it from the perspective of the so-called environmental life cycle (beginning from the acquisition of primary materials for its production, and ending with its utilisation). The primary source of harmfulness of the product that its manufacturer wants to eliminate may be, for example, wrong composition or method of manufacturing of any of its components or materials manufactured by other companies (see Sobańska, 2010, Chapter 13; Kabalski, 2010).

Business relationships with stakeholders have been identified by the IASB as one of the key elements of the Management Commentary. It is necessary to identify them, determine their impact on the results and value of the company, and describe the way the management manages them. The term "stakeholder relations" is broader than business relationships in the value chain or network. Perhaps it would be appropriate to specify the basic types (directions) of these relationships. It is important, however, that the issue of the business entity's links with other entities and their strategic importance has been included in the recommendations of the IASB.

Writing about external relations of the company, it is impossible not to mention internal relationships. These also have undergone important changes in recent years. In the place of traditional organisational structures, there appear molecular ones, based on units. Companies are collections of distributed, but networked individuals and teams that are each other's customers and suppliers (Kowalczewski, 2009, p. 83). Relationships within the company are becoming loose (i.e. they lack formal lines of command) and less stable (they undergo transformations, new ones appear in the place of some older ones). The boundaries that traditionally structurally separate employees are disappearing (see Schermerhorn, 2008, p.185). So are we dealing with the twilight of organisational structures (not only the traditional ones, but any structures at all)? If so, is it not anachronistic of the IASB to recommend presenting the company's structure in the Management Commentary? According to P. Drucker (2009, pp. 21-25), one of the leading authorities in the field of management, organisational structure is still needed. Enterprises and institutions must be somehow organised. Moreover, the organisational structure must be transparent (understandable especially for employees). One of the basic rules of organisation is the existence of a hierarchy. Even in a maximally flattened organisation, composed of people equally validated to make decisions, there must be the captain, i.e. someone who makes the final decision (Note 11). To sum up Drucker's view, it can be said that the structures have existed, exist and probably will exist. It is only their forms that undergo changes. Presenting the company's internal structure to the users of the Management Commentary makes sense (although in some cases it may be difficult to describe or depict). Since there is no one form of organisation suitable in all conditions (which will be mentioned further), developing the organisational structure is one of the most important and most difficult tasks of the company's management.

\subsection{Resources, intellectual capital and knowledge}

Another element whose presence will be looked after in the Management Commentary is the result of several different, albeit largely similar or interrelated paradigms and theories (Note 12). Let us start from the resource concept (theory) of competitive advantage (Barney, 1991, pp. 99-120; Mahoney, Pandan, 1992, pp. 363-380; Petraf, 1993, pp. 179-191). It says that gaining sustainable competitive advantage in conditions of uncertainty depends on the ability to acquire, use and multiply specific resources by the company. It is about such resources that, first of all, allow the company to react quickly to changes and, secondly, are difficult to copy by competitors (Koźmiński, 2004, p. 92). These are the features displayed primarily by "soft" resources. These include: the company's brand and its products, market access and share in it, the reputation of the company (not just as a manufacturer of certain products), corporate culture (norms, values, role models), defined characteristics of human resources (skills, attitudes, aspirations), knowledge (information resources collected by the company). 
Most of these and similar resources form the so-called intellectual capital (Note 13).

It is believed that the theory of business determined by intellectual capital has the greatest impact on contemporary understanding of the company (Noga, 2009, p. 205). This determination means that it is only (or predominantly) the intellectual capital that determines the competitive position of the company. Furthermore, it is crucial for growth, and its development in the enterprise has a positive dimension for the general public (Noga, 2009 , p. 206). This means that information about the company's intellectual capital is equally useful for its shareholders, as for other stakeholders. Does the Management Commentary, in the form proposed by the IASB, contain elements consistent with the resource theory of competitive advantage and the theory of a company determined by its intellectual capital? To a large extent, it is so. First of all, it was recommended to disclose the information about critical resources affecting the value of the company (including their status in relation to the needs), methods of their use and methods of managing them. What are the resources in question? The IASB talks about financial and non-financial resources. Among the latter, it lists human and intellectual capital resources. It makes no sense to find fault in the fact that human capital is probably a part of the intellectual capital in the light most definitions (Note 14). What can raise reservations, however, is that intellectual capital has been enumerated by the IASB "in one breath" alongside a few other resources (factors), mostly financial, critical for achieving the objectives of the company. Since businesses and the economy are now determined by intellectual capital, it should be exposed (especially that unlike the financial elements listed next to it, it is not reflected in financial statements [Note 15]). Exposing this element could be accompanied by mentioning the main components of intellectual capital, either in the form of a "loose" list or in accordance with a certain structure, for example, according to the definition of T. Stewart. He distinguishes three main components of intellectual capital: human (skills, attitudes), structural (intellectual property, methodologies, procedures, software, documents, etc.) and client (customer relationships) (Stewart, 1997, pp. 53-142). Inspiration for the content of information on intellectual capital can also be found in practice. One of the best examples is the Skandia company, a pioneer in the field of reporting information on intellectual capital to external users (Note 16). In summary, it can be concluded that the paradigm of a company determined by intellectual capital would be fully reflected in the recommendations of the IASB, if intellectual capital were reflected in the Management Commentary in a way corresponding to its importance in the modern economy.

A special kind of intangible resources for businesses today is knowledge (Koźmiński, 2004, p. 94; Drucker, 2009, p.145). Agreement with this statement among specialist is so widespread that one can speak of a paradigm of competition based on knowledge. According to the shortest definition, knowledge is a resource of information (Koźmiński, 2004, p. 94). Knowledge can be direct (explicit, formalised, possible to transmit, display and encode) and indirect (individualised, intuitive, resulting from personal experience) (Szycha, 2007, p. 207). It applies to all elements of reality in which the company operates: competitors, customers, partners, employees, society, public institutions, etc. (Koźmiński, 2004, p. 95). It has many forms. Since it is so important in today's economy, it would be advisable to highlight its importance in the Management Commentary (as a part of the intellectual capital).

\subsection{Paradigm of focus on the results}

According to Drucker, one of the most important new management paradigms relates to its functions and objectives. The function of management is to care about the results of the organisation. The aim of management is to define the expected results, then such organisation of available resources that is able to ensure the achievement of these results (Drucker, 2009, p. 48). It might seem that Drucker considers a new paradigm something that has long been clear, both to theorists and practitioners of management. But the point is that management has traditionally focused on the inside of the company "on its efforts, and even on the costs alone", while "it should focus on results and performance". According to Drucker, the development of information technology even exacerbated the scale of this negative phenomenon. In the IASB's guidelines, the achieved and expected financial and non-financial results of the company are one of the five basic elements of the Management Commentary. What is more, it has been recommended that the results are presented in relation to the objectives set by the management and the strategies adopted for their implementation.

\subsection{The paradigm of leadership}

Another paradigm of modern management to be confronted with the Management Commentary concerns the role of the manager of the company. Today, this person should be a leader. Leadership is distinguished by the way of influencing subordinates. According to Drucker, employees should be more and more often viewed as partners (Drucker, 2009, p. 30) (Note 17). Partnership implies equality, so the partners are not given commands. Instead, you must convince them and inspire. Leadership is largely about building the commitment and enthusiasm 
(Schermerhorn, 2008, p. 238) (Note 18). Such an atmosphere is essential to ensure that employees fully use their ability to achieve the objectives of the company. The leader cannot let the company lose its momentum due to boredom and burnout of employees. Leadership also means: the creation of teamwork, participation in it, proactive attitude, encouraging self-reliance and ingenuity (asking questions, expressing doubts, breaking schemes), having and formulating sustainable guiding ideas uniting the organisation, celebrating the achievements, ability to make compromises (but not "rotten" ones), purity of intention, and consistency in action (but not "asinine stubbornness"). The leader should be a model of conduct, also in the ethical dimension. Interestingly, this person does not have to be a specialist in the areas the subordinates are responsible for. The task of the manager is the harmonisation of the activities of other people (see Drucker, 2009, p. 29; Schermerhorn, 2008, pp. 237-238). Being a leader is largely an art. It requires, of course, having certain expertise, but is equally associated with certain personality traits, emotional intelligence, moral backbone and intuition. According to most experts, in the context of increasing uncertainty, strong leadership (strategic leadership, visionary leadership) is the most desirable element of the manager's profile (Koźmiński, 2004, p. 84).

If the profile of the manager is so important to the survival and development of the organisation, this should be reflected in a report such as the Management Commentary. However, the IASB does not require preparation of a portrait of the members of the company's top management. It is even impossible to treat this as a disadvantage. First of all, companies publish information about their management boards (in the financial statements or next to it) (Note 19). Secondly, how to prepare such a portrait in order to reflect what is understood as the leader's trait (Note 20). Despite that, it is worth to try (Note 21).

\subsection{Contingency theory}

At the end, let us focus on the paradigm of contingency theory. It assumes that, in different places, at different times and in different conditions, different methods work well. In other words, there are no good solutions for every occasion. For example, Drucker says that the search of one ideal organisational structure by management specialists is a waste of time. Instead, different forms of organisation should be developed and verified to see which of them operates best in practice (Drucker, 2009, p. 25). The same is valid for other managerial functions. Contingency theory is clearly present in the Management Commentary (Note 22).The IASB states that the form and detailed content of the report may be different. The issues to which the management board devotes special attention depend on the specific facts and circumstances (nature of the activity, the adopted strategy, the characteristics of the environment). With this flexible approach, individual entities disclose the information that due to the nature of their activities is most important. While admitting contingency approach in developing the Management Commentary, the IASB had to consider the issue of comparability, which is one of qualitative characteristics conditioning usefulness of the information (Note 23). In accordance with it, it suggests that the entity presents performance measures and indicators adopted in a given industry.

\section{Summary}

Certainly not all relevant paradigms (theories, concepts) of modern management are included in this article. Maybe some of them have been presented in a too simplistic way. The readers are encouraged to treat this article as a proposal of the direction of analysis and evaluation of the Management Commentary (and reports of a similar nature) and an incentive to an in-depth discussion on this topic. Finally, it should be added that the synthesis of the considerations contained in this article, consisting in determining the Management Commentary's degree of compatibility with modern management paradigms, does not seem to make sense. How to measure this degree? One could, of course, easily construct and calculate a more or less sophisticated indicator, but it would mean about as much as the information provided in advertisements of a face cream that it rejuvenates the skin by $73 \%$. Because of that, let the table 1 serve as a conclusion.

What are the benefits of the analysis presented in the article? First of all, it may be helpful for governing bodies when making recommendations on management information as an element of financial reporting (Note 24). Secondly, it can provide inspiration to companies preparing their Management Commentary. And last but not least, it can help to raise awareness in accounting theoreticians and practitioners of the need to see its role, problems and solutions in a broader economic and social context, especially its close connection with management. Observing the accounting environment in Poland, one often gets the impression that this field of knowledge is isolated from other aspects of reality (both in a micro and macro scale), that it works for itself, instead of being part of the system (this can be seen in many companies and institutions) (Note 25). It has difficulty adapting to new conditions, assimilating new ideas and opening up to new areas. In many new developments, it sees an attack on its identity, instead of a chance to broaden or even change its cognitive horizons, which would enable it to continue to fulfil an important role in the economy. 


\section{References}

Barney J. (1991). Firm's resources and sustained competitive advantage. Journal of Management, 17(1), 99-120. http://dx.doi.org/10.1177/014920639101700108

Drucker P. F. (2009). Zarzadzanie XXI wieku - wyzwania. MT Biznes, Warszawa.

IASB (2010a). Conceptual Framework for Financial Reporting. Londyn.

IASB (2010b). IFRS Practice Statement Management Commentary: A framework for presentation. Lodnyn.

IASB (2010c). International Financial Reporting Standards. Londyn.

Hammer, M. (2001). The superefficient company. Harvard Business Review, 79(8), 82-91.

Kabalski P. (2009a). Cele sprawozdań finansowych według projektu Ram konceptualnych sprawozdawczości finansowej. Zeszyty Teoretyczne Rachunkowości, 48(104). Stowarzyszenie Księgowych w Polsce-Rada Naukowa, Warszawa.

Kabalski P. (2009b). Comments on the Objective of Financial Reporting in the Proposed New Conceptual Framework. Eurasian Journal of Business and Economics, 2(4), 95-111.

Kabalski P. (2010). Rachunkowość zarządcza w procesie zarządzania środowiskiem. In Gralewski J., \& Marcinkowski A. (red.), Rozwój zrównoważony - zarzq̨dzanie technologiami. Wydawnictwo Media Press.

Kouzes J. M., \& Posner B. Z. (1988). The Leadership Challenge...Success. (4th ed.). John Wiley \& Sons.

Kowalczewski W. (red.) (2009). Wspótczesne paradygmaty nauk o zarzadzaniu. Warszawa: Difin.

Koźmiński A.K. (2004). Zarzqdzanie w warunkach niepewności. Warszawa: PWN.

Mahoney J., \& Pandan J. R. (1992). The resource-based view within conversation of strategic management. Strategic Management Journal, 5(13), 363-380. http://dx.doi.org/10.1002/smj.4250130505

Makower J. (1994). Beyond the Bottom Line: Putting Social Responsibility to Work for Your Business and the Word. Nowy Jork: Simon \& Schuster.

Noga A. (2009). Teorie przedsiębiorstw. Warszawa: PWE.

Petraf M. A. (1993). The cornerstone of competitive adventage: A resource-based view. Strategic Management Journal, 14, 179-191. http://dx.doi.org/10.1002/smj.4250140303

Sobańska I. (red.) (2010). Rachunkowość zarzadcza, Podejście operacyjne i strategiczne. Warszawa : CH Beck.

Schermerhorn J. R. (2008). Zarzqdzanie. Warszawa: PWE.

Stewart T. A. (1997). Intellectual Capital. Nowy Jork: Doubleday.

Suszyński C. (red.) (2007). Przedsiębiorstwo Wartość, Zarzq̨dzanie. Warszawa: PWE.

Szychta A. (2007). Etapy ewolucji i kierunki integracji metod rachunkowości zarzq̨dczej. Łódź: Wydawnictwo Uniwersytetu Łódzkiego.

Waddock S. A., \& Grave S. B. (1997). The Corporate Social Performance-Financial Performance Link. Strategic Management Journal, 303-319. http://dx.doi.org/10.1002/(SICI)1097-0266(199704)18:4<303::AID-SMJ869>3.0.CO;2-G

Notes

Note 1. It was assumed that discussing the entire contents of the IASB's document makes no sense and that a brief description of the essence and the main elements will be sufficient from the viewpoint of the article. Readers wishing to form a detailed opinion on the Management Commentary or accurately verify the validity of the author's opinion can read the article while having at hand the full original content of the Management Commentary (available at www.ifrs.org).

Note 2. Of course, in accordance with the systemic approach, these elements are closely linked and interact with each other.

Note 3.The direction of integration of management accounting methods is described in depth by A. Szycha (2007).

Note 4. In general, business entities disclosure only the information that is clearly indicated in the regulations, standards or recommendations.

Note 5. Conceptual Framework for Financial Reporting (IASB, 2010). 
Note 6. In the case of some organisations, this impact is enormous. The recent natural disaster in the Gulf of Mexico caused by the BP concern may serve as an example.

Note 7. Since reliability and honesty of employees has an impact on the efficiency of management, it is wrong to suppose that the ethical aspects of the company are irrelevant to the providers of capital, even if they are oriented only to increase the company's value.

Note 8 . The problem of managing cultural diversity is one of the elements shaping the holistic paradigm of management (Kowalczewski, 2009, p. 27).

Note 9. At a push, it can be concluded that it is contained in the element "human resources", which is listed as one of the key types of resources of entities.

Note 10. Of course, what counts is not only the number of links in the network, but also their quality (durability on the one hand, on the other - flexibility) and the position of the entity in the network.

Note 11. In the absence of any hierarchy in an enterprise, a problem would arise of who should develop (or confirm) theManagement Commentary.

Note 12. Due to the fact that, in the opinion of the author of this article, these paradigms and theories lead to one conclusion as to the desired content of the Management Commentary, they will be discussed together without focusing on the differences between them.

Note 13. It should be emphasised that in the literature there are many terms that function in parallel, such as intangible assets, knowledge capital, invisible assets, and intellectual capital. The very definitions of intellectual capital are so numerous that presenting even the most important ones would require a separate study. From the perspective of this publication, to consider whether these different terms are the same or not, or what is included in intangible assets (or intellectual capital) by individual authors does not make much sense. In the further part of the article, the term "intellectual capital" will be used.

Note 14. For example, in the concept of T. Stewart and L. Edvinsson.

Note 15. As a result of the provisions of International Accounting Standard 38 ("Intangible Assets"), the elements of intellectual capital are generally not recognised as assets on the balance sheet (IASB, 2010c).

Note 16. Reports can be found at www.skadnia.com.

Note 17. Drucker writes that this is because of the mobility of the employee and the fact that the employees have access to the key means of production, which today is knowledge. In this situation, employees should be treated more like volunteers. They must have a clear view of the goals of the organisation and identify with them, be motivated to act, and infected with a vision of great challenges. They must see the results of their efforts and be appreciated for them. Employees-volunteers are not compelled to act. On the contrary - they do not have to, but want.

Note 18. The author cites Kouzes and Posner (1988), who called for the introduction of emotion to the enterprise, so as to mobilise not only the minds, but also hearts.

Note 19. Sometimes biographies of board members occupy a page of text.

Note 20. Especially since the portrayed and the portraying is the same person. It is something different to write about yourself facts only (e.g. doctorate in economics and fifteen years of work in the industry), and something completely different to objectively present your personality.

Note 21. Hard evidence confirming the fact that someone has the characteristics of a leader are his or her achievements from the past (e.g. successful missions in managerial positions in previous workplaces). Soft evidence (circumstantial evidence) may be: education, university degree and courses, hobbies, family sphere, non-business activities and achievements (e.g. successes in other fields that require the characteristics typical of a leader, activity in community organisations proving the ability to work with people and care about the fate of others, etc.). And by the way - the question of leadership is a proof that the holistic management paradigm also houses the psychology (the great importance of psychology for economic sciences is best evidenced by the Nobel prize awarded in 2002 to Daniel Kahneman's research; the interested readers are recommend to see the following websites: http://nobelprize.org/nobel prizes/economics/laureates/2002/kahneman-autobio.html and $\mathrm{http}: / /$ www.princeton.edu/ kahneman).

Note 22. Contingency approach is characteristic of the International Financial Reporting Standards. It is evidenced by, among others, the choice of accounting policy permitted in many standards and allowing own judgement of the entity when classifying a number of transactions and events. Another expression of the 
contingency approach is that standards mandating or permitting measurement of current value do not specify one discount rate appropriate for all situations. Similar examples could be multiplied.

Note 23. In the new Conceptual Framework, it is the so-called enhancing qualitative characteristic (in relation to fundamental characteristic: relevance and faithful representation).

Note 24. Of course, one should not get the impression of overestimation of the importance and relevance of the considerations contained in this article. Without false modesty - the author knows his place in line.

Note 25. Obviously, it is a generalisation, perhaps even exaggerated. Not all accounting theoreticians and practitioners work in such a way, perhaps it is even the minority. Nevertheless, the phenomenon is noticeable and disturbing.

Table 1. Reflection of modern management paradigms in the Management Commentary

\begin{tabular}{|c|c|}
\hline Holistic paradigm (holistic and environmental) & $\begin{array}{l}\text { Reflected in general, implicit way, without any } \\
\text { indication of the main building blocks of a } \\
\text { comprehensive (holistic) picture of the company }\end{array}$ \\
\hline Environmental aspect & No direct reference \\
\hline Ethical aspect & No direct reference \\
\hline $\begin{array}{l}\text { Aspect of organisational culture and } \\
\text { multiculturalism in the enterprise }\end{array}$ & No direct reference \\
\hline Systemic approach & $\begin{array}{l}\text { Included (in relation to elements of the Management } \\
\text { Commentary) }\end{array}$ \\
\hline Process concept of a company & Included \\
\hline $\begin{array}{l}\text { The paradigm of value (for the customer, the } \\
\text { owner and other stakeholders) }\end{array}$ & $\begin{array}{l}\text { Included, but imprecisely defined, without explanation } \\
\text { to whose value it relates (it can be assumed that it is the } \\
\text { value for the owners; if so, the value for customers and } \\
\text { other stakeholders has been omitted) }\end{array}$ \\
\hline $\begin{array}{l}\text { The paradigm of relationships with other entities } \\
\text { as a source of competitive advantage and value }\end{array}$ & Included (in general terms) \\
\hline Resources concept of competitive advantage & Reflected \\
\hline $\begin{array}{l}\text { Theory of enterprise determined by intellectual } \\
\text { capital }\end{array}$ & $\begin{array}{l}\text { Reflected (albeit the critical importance of the } \\
\text { intellectual capital is not exposed) } \\
\text { No direct reference }\end{array}$ \\
\hline Paradigm of knowledge-based competition & \\
\hline Paradigm of focus on the results & Reflected \\
\hline $\begin{array}{l}\text { The paradigm of leadership as the most } \\
\text { important element of the manager's profile }\end{array}$ & Not reflected \\
\hline Contingency theory & Included \\
\hline
\end{tabular}

Source: own study 